УAK 551.763:552,14+551.35(47-15)

Y.M. Senkovsky, K.G. Grigorchuk, V.P. Gnidets, Y.V. Koltun, I.T. Popp, N.Y. Radkovets

\title{
GEOLOGICAL- AND CHEMICAL-PALEOOCEANOGRAPHIC ASPECTS OF SEDIMENTOGENESIS OF THE CARPATHIAN- BLACK SEA SEGMENT OF TETHYS OCEAN
}

\author{
Ю.М. Сеньковський, К.Г. Григорчук, В.П. Гнідець, Ю.В. Колтун, І.Т. Попп, Н.Я. Радковець \\ ГЕОЛОГО- ТА ХІМІКО-ПАЛЕООКЕАНОГРАФІЧНІ АСПЕКТИ СЕАИМЕНТОГЕНЕЗУ КАРПАТО-ЧОРНОМОРСЬКОГО \\ CEГMEHTУ OKEAHY TETИC
}

This study represents a scientific synthesis of the results of authors' investigations on the problem "Geological and chemical paleooceanography of Carpathian-Black Sea segment of the Tethys ocean". Examination of sedimentary processes, which took place within the ancient continental margin, allowed studying of the maim features of terrigenous, edaphogenic and biogenic sedimentation and identifying in the lithological record of Precambrian-Phanerozoic a series of anoxic events, with which a range of mineral resources is related in the region under study. Analysis of data on geological and geochemical nature of the present-day upwelling in the World Ocean and obtained results on the nature of the upwelling process in the Tethyan part of the Carpathian-Black Sea region in Mesozoic-Cenozoic allowed distinguishing among the existing sedimentary formations of marine (oceanic) range a separate genetic type - «upwelling formation", which is suggested to be introduced into the doctrine about the sedimentary deposits, and this new scientific direction in geological paleooceanography to distinguish under the term "upwelling geology" and consider it as an original part of the Earth sciences. Keywords: geological and chemical paleooceanography, ancient continental margin, Tethys, upwelling formation, anoxic events.

Аана робота являє собою науковий синтез результатів досліАжень авторів з проблеми "Геологічна і хімічна палеоокеанографія Карпато-Чорноморського сегменту океану Тетіс". Вивчення процесів осаАонагромаАження, які проходили в межах Аавньої континентальної окраїни, Аало можливість АосліАити особливості теригенної, едафогенної і біогенної седиментації та іАентифікувати в літологічному літописі докембрію-фанерозою серію аноксичних подій, з якими пов'язаний цілий ряА корисних копалин в регіоні. Аналіз даних про геологічну і геохімічну природу сучасного апвелінгу в Світовому океані та одержані результати про природу апвелінгового процесу в тетиАній частині Карпато-Чорноморського регіону в мезозой-кайнозої дав підставу виАілити сереА відомих осадових формацій морського (океанського) ряду окремий їх генетичний тип - «апвелінгова формація", який і пропонується ввести у вчення про осаАові утворення, а цей новий науковий напрям у геологічній палеоокеанографії виділяти піА назвою “апвелінгова геологія» і розгяяАати його як самостійний розділ в науках про Землю.

Ключові слова: геологічна і хімічна палеоокеанографія, давня континентальна окраїна, Тетис, апвелінгова формація, аноксичні події.

\section{INTRODUCTION}

During the last decades the sedimentological aspects of investigation of the oil- and gas-bearing provinces gained the principal importance for determination of the further directions oil and gas exploration, especially for studies of the mature oil and gas basins, the intense exploration and production of hydrocarbons in which lasts already for a long time. To such kind of basins belongs one of the world's oldest petroleum provinces - the Carpathian oil- and gasbearing basin. Taking into account of the sedimentological aspects is also principal for investigation of the sedimentary successions, for which the results of the long-lasting exploration works and the discovery of few small fields evidences the potential of the region for further oil and gas prospecting, for example the Black-Sea - Crimean petroleum province.

The modern achievements in study of the sedimentary processes in the World Ocean together with the newest data of organic geochemistry provide understanding of the entire logicality of the oil- and gas-bearing sequences formation. The decisive processes in this logicality are the deposition, extension and evolution of the petroleum-source beds, which take place under the influence of a range of factors of global, regional and local scales.

This study represents a scientific synthesis of results of the authors' investigations on the problem "Geological and chemical paleoceanography of the Carpathian-Black Sea segment of the Tethys ocean".

\section{METHODS}

The results, presented in this study, have been obtained on the base of mineralogical and petrographic investigations of rocks of Late Precambrian to Paleogene age of the Carpathian-Black Sea region of Ukraine. Lithological-facial studies allowed distinguishing the variety of sedimentary environments within the study area. Sedimentologic-paleoceanographic analysis resulted in construction of sedimentary models, while the historic-lithogenetic approach allowed tracing the postsedimentary evolution of sedimentary successions.

GEOLOGICAL-PALEOCEANOGRAPHIC BACKGROUND The history of geological evolution of the southwestern part of the continental margin of Tethys 
covers the time span from Late Precambrian to Miocene. During this time within the study territory the complex and variable sedimentary processes, which were controlled by of both global and regional scale events took place. From the point of view of geological paleoceanography the investigation of the Mesozoic-Cenozoic stage of the development of the Carpathian-Black Sea region allows tracing the main features of formation of the sedimentary-rock basins of the ancient continental margins.

In Late Mesozoic the Carpathian-Black Sea basin was closely related with the circulation system of the Tethys ocean and occurred mainly under the influence of the ancient anticyclonic Mediterranean ring (Senkovsky, Demchenko, 1988). The existing at that time tropospheric and hydrospheric processes caused the domination of the directions of the water mass movement from west to east. This, correspondingly, had a certain influence on the vectors of the "through-pass accumulation" in the end points of the different age sedimentary basins of terrigenous and biogenic material.

The deposits of Late Mesozoic (Jurassic, Cretaceous), which are spread over this vast marine area, from the point of view of the environments of their formation, nature and spatial distribution are clearly fixing the sediments of epi-pelagic and meso-pelagic parts of the Carpathian-Black Sea basin (Pasternak et al., 1987; Senkovsky, 1977, 1978). The epi-pelagic sediments have been deposited within a shelf, while the meso-pelagic ones mainly represent the deposits of the thick succession of the Carpathian flysch.

\section{RESULTS AND DISCUSSION}

Study of the sedimentation processes, which took place at every of the three tectonic ledges of the ancient continental margin, allowed stating a different intensity and scale of terrigenous, biochemogenic and biogenic sedimentation (Senkovsky et al., 2004). The latter one was dominated by the processes of both carbonate and silica deposition.

While tracing the evolution of the biogenic sedimentogenesis, its maximums in Late Jurassic and Late Cretaceous have been established. The rest geological epochs of the Late Mesozoic were characterized by the accumulation of the clastic material. This concerns to both epi-pelagic and mesopelagic parts of the Tethian basin.

Processing and interpretation of the data, related to the ancient sedimentogenesis allowed adding the knowledge about the specific character of the environments of the Carpathian flysch formation. In Cretaceous and Paleogene in the meso-pelagic part of the basin at the base of the continental slope the huge submarine fans have been formed. They have been complicated by the different age morphostructures, which differed by the volume of the accumulated material as well as by lithological and facial composition and the structural features. There is every reason to state that within the margin of the investigated part of the European craton, covered by the Mesozoic-Cenozoic seas, occurred the submarine fans of pre-Wislok, pre-Stryi (pre-Dnister), pre-Ustechko river bed-graben, pre-Dnipro. The first two fan-forming rivers were the main transit ways for the terrigenous material, which arrived from the vast territory of the Northern Dryland. In our opinion, the most intense river transport was provided by pre-Wislok with its huge submarine fan. The terrigenous material, derived by pre-Wislok river, was distributed by submarine currents of north-eastern direction along the continental slope and caused the accumulation of the prevailing volume of the flysch sediments of the Ukrainian Carpathians and adjacent regions. The scope of terrigenous sedimentation within the submarine fans can be demonstrated at the example of submarine fan of Amazon river (Fig. 1). Just similar scale submarine fans have provided the accumulation of the huge succession of the Carpathian flysch within the ancient continental margin of the Tethys ocean. It should be noted, that the biogenic component made a significant volume, which, together with terrigenous material, has been involved into the processes of the different age flysch formation. The ancient anticyclonic situation in troposphere and hydrosphere of the study region caused the surface and submarine transfer of the terrigenous material in sub-latitudinal direction, namely from the west to the east. Such specific dynamics of the ancient marine basin has determined the multi-kilometer transit of both clastic and biogenic components. After a long lasting transfer of sediments and submarine fans formation the stage of sedimentogenesis has finished and the further post-sedimentary processes resulted in the flysch succession formation. These conceptual conclusions in our opinion raise the question about the necessity of some revision and new interpretation in a light of the new data of the environments of the Carpathian flysch formation. In particular, this refers to determination of the geographical position of sources and ways of supply of the terrigenous material and its accumulation in the end points of sedimentary basins. The structuralfacial zoning of the Carpathian flysch is explained by the way of submarine fans distribution in relation to the spatial occurrence of submarine morpho-structures, which, as we see it, had a sub-longitudinal direction. 


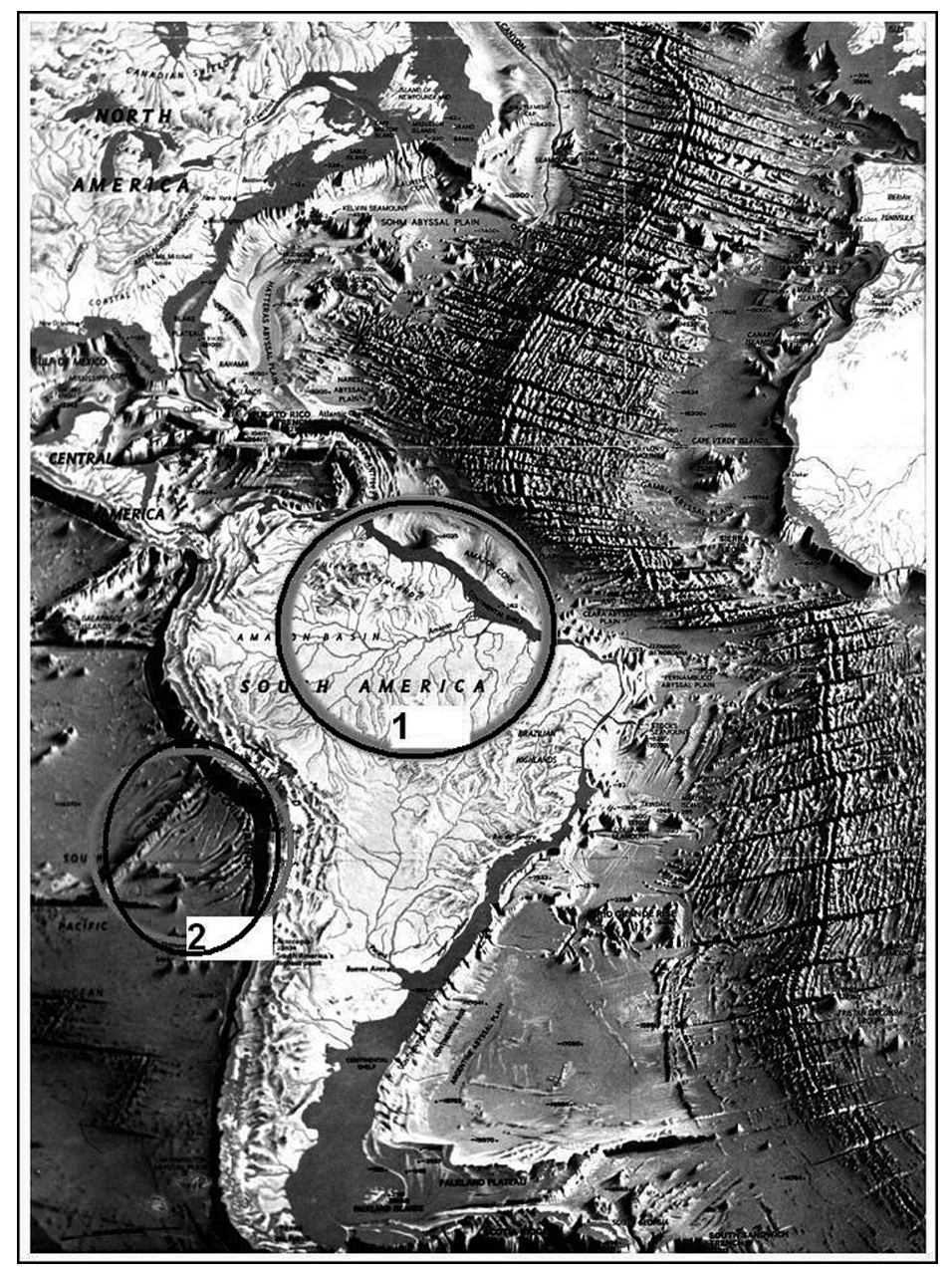

Fig. 1. Structural elements of the present-day World Ocean floor. 1 - Amazon river fan; 2 - a system of submarine ridges.

Just similar system of submarine ridges is observed in different parts of the present-day World Ocean (Fig. 1). Space between separate ridges and highs played the role of certain structural traps. They were filled with sediments, which arrived from the European continental block, as well as with edaphogenic material, forming separate lithogenetic types of fans in the Carpathian sedimentary basin.

Regime of sedimentation in the Carpathian flysch basin has been controlled by the sea-level changes. At high sea-level stand the sediments accumulated mainly at the first level of the avalanche sedimentation (shelf). At lowering of the sea-level the sedimentary material was transferred to the second level of the avalanche sedimentation (base of the continental slope) by different kinds of the gravity flows. In the succession of the Carpathian flysch a certain correlation of the terrigenous sedimentation with the eustatic sea-level changes can be observed. Mainly sandy sequences are correlated with the phases of the sea-level drop. These phases took place in
Aptian-Early Albian (Upper Shypot beds), Paleocene (Yamna formation), Middle Eocene (Vyhoda formation), Oligocene (thick sandstone layers of Menilite and Krosno formations). The prevailing occurrence of the clayey and biogenic sediments is characteristic to the periods of the high sea-level stand: Late Cretaceous (Stryi formation), Early (Manyava formation) and Late (Bystrytsya formation) Eocene, Early Oligocene (Chert horizon).

Combination of different paleoceanographic factors in the Cretaceous-Paleogene history of the Carpathian sedimentary basin has resulted in formation of the special flysch succession, which comprises both thick organic-rich sequences and thick sandstone layers, which is of great importance for the assessment of the petroleum potential of the region.

Among the many-sided problems of the chemical paleoceanography to the youngest branches should be regarded the chapter - geology and geochemistry of the ancient sedimentary upwelling systems of the World Ocean. The authors suggest to introduce 
this new scientific direction in geological paleoceanography under the name "upwelling geology" and to consider it as a separate chapter in Earth Sciences. Analysis of the published data on geological and geochemical nature of the present-day upwelling in the World Ocean as well as the obtained by the authors of this study results on the nature of the upwelling process in the Tethyan part of the Carpathian-Black Sea region in Mesozoic-Cenozoic allowed distinguishing among the known marine (oceanic) sedimentary formations their separate genetic type - "upwelling formation", which is suggested to introduce into the theory of the sedimentary formations.

In the sedimentary sequence of the CarpathianBlack Sea continental margin of Tethys ocean we have distinguished three ancient upwelling formations, which are traced in the deposits of Vendian, Cretaceous and Paleogene periods (Fig. 2). In separate parts of the territory to these specific sedimentary beds are related oil- and gas-bearing, black shale, phosphorite-bearing, opal-cristobalite and chalcedonolite beds (Carpathian, Black Sea-Crimean petroleum provinces, Volyn-Podillya and Moldova phosphorite-bearing and silicite-bearing provinces, Carpathian and Black Sea black shale provinces).
In the history of geologic evolution of the south-western continental margin of Tethys ocean during Late Precambrian-Phanerozoic a range of anoxic events took place, which have reflected in the lithological record of this territory and had an essential influence on the sedimentary processes of these successions (Senkovsky et al., 2012b). The corresponding rock sequences, formed under the influence of these events, have formed during the diagenesis and catagenesis the geological formations, which comprise a range of mineral resources in the region.

The oldest anoxic event is fixed in the sequence of Late Vendian and is represented by Kalus Beds. These organic-rich deposits have been formed in an anoxic basin of the estuary type (the Baltic-Paleotethyan type), which we suggest to mark with an index OAE-V. Kalus black shale strata at the territory of Ukraine occur within the Volyn-Podillya monocline and are resting on the Ryphean-Lower Vendian deposits or on the crystalline rocks of the Precambrian basement. It was established (Senkovsky et al., 2012b) that deposition of Kalus black shales took place in epi-pelagic Dnister paleobasin, which was connected with the dynamic system of the World Ocean. In zones of coastal

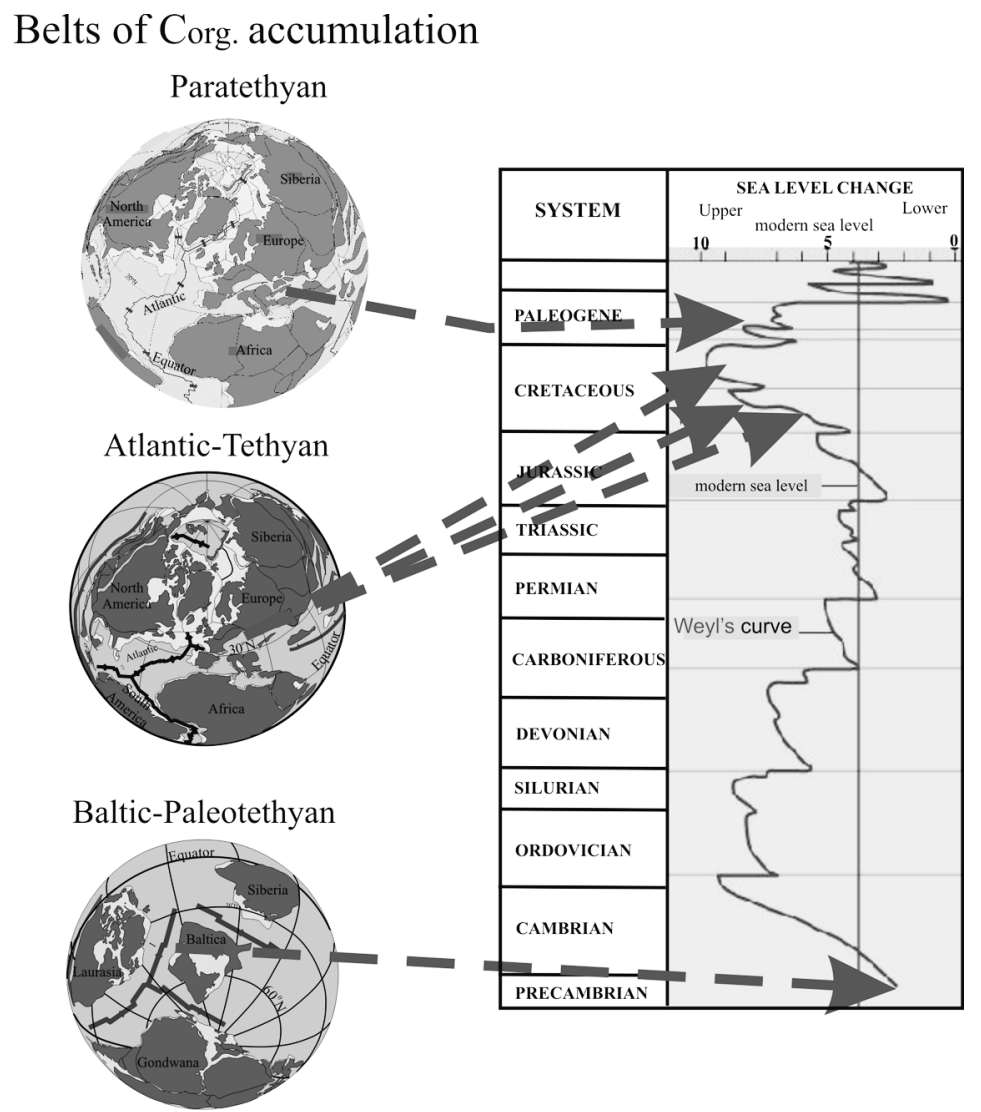

Fig. 2. Main anoxic events, fixed in the lithological record of the Carpathian-Black Sea continental margin of Tethys. 


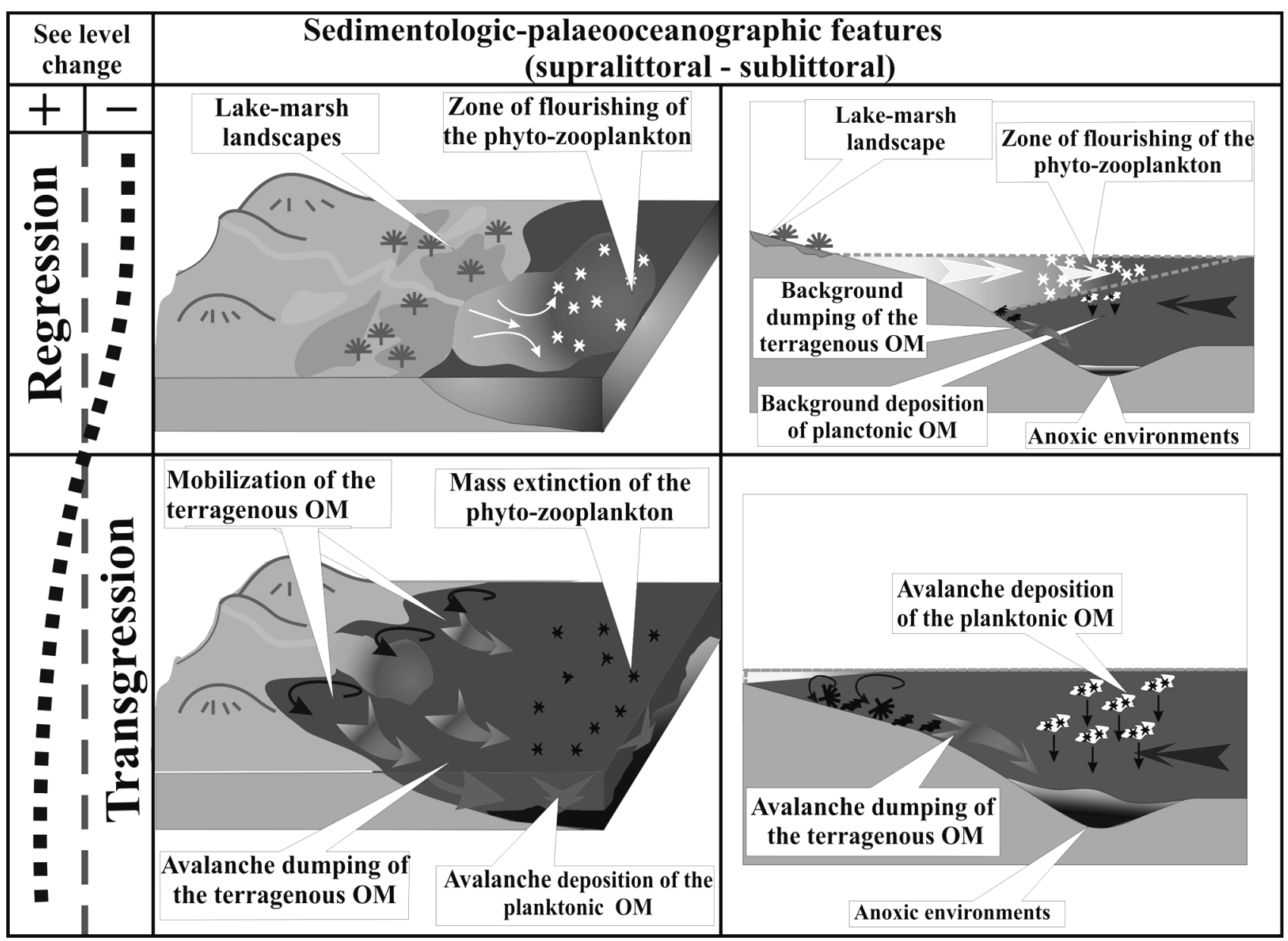

Fig. 3. Principal model of sedimentation in transgressive-regressive cycling conditions (anoxic sedimentation of the estuary type).
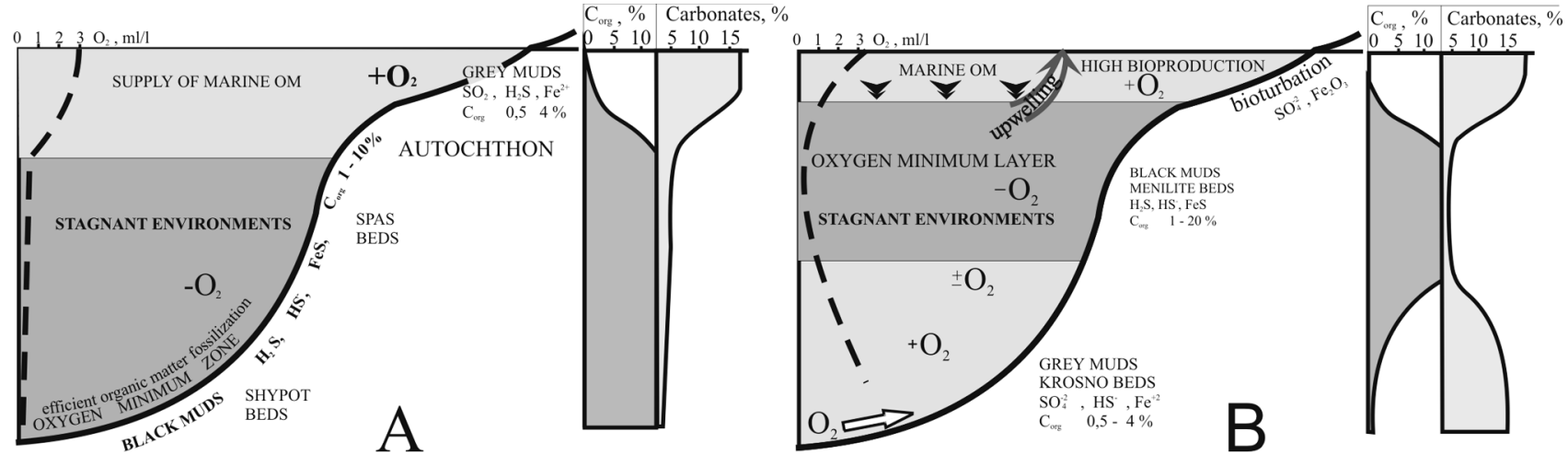

Fig. 4. Model of deposition of organic-rich sediments in the meso-pelagic part of the Carpathian segment of continental margin of Tethys.

A - Early Cretaceous (Shypot and Spas formations); B - Ologocene (Menilite formation).

upwelling the cold water inflow, enriched with biogenic elements $\left(\mathrm{SiO}_{2}, \mathrm{P}, \mathrm{N}\right)$ into the upper part of the water column of the open sea basin, caused the increase of the primary biogenic production $\left(\mathrm{C}_{\text {org. }}, \mathrm{P}\right)$. As a result of the gradual closure of the Dnister depression the basin has undergone the regression and, as a result, the connection with the dynamic system of the World Ocean has disappeared, which caused the accumulation of organic matter and forming of the phosphate concretions of the phosphate gel in anoxic environments.

Three Cretaceous anoxic events (Schlanger, Jenkyns, 1976) showed in a different way in the sedimentary succession of the region (Senkovsky 
et al., 2012b). First of them, the Early Cretaceous Barremian-Albian covered the great part of the sedimentary basin, including its epi- and masopelagic parts (Atlantic-Tethyan paleobasin). The anoxic events of the Late Cretaceous - the Cenomanian-Turonian and the Coniacian-Santonian, had a limited influence on paleoceanography of the region. For epi-pelagic basin of the Black SeaCrimean segment of Tethys the estuary type of anoxic basins was typical (Fig. 3).

In Carpathian basin in Barremian-Albian the oxygen-minimum layer covered the entire mesopelagic part of the basin, providing the formation of the black shale succession in a basin scale (Shypot and Spas Beds) (Fig. 4A).

In Oligicene an anoxic event covered the mesopelagic part of the Carpathian-Black Sea continental margin (the para-Tethyan paleobasin) and caused

\section{REFERENCES}

Pasternak S.I., Senkovsky Y.M., Gavrylyshyn V.I., 1987. Volyno-Podillya in Cretaceous period. Kyiv, Naukova dumka, 260 p. (In Ukrainian).

Senkovsky Y.N., 1987. Lithogenesis of siliceous successions of south-west of USSR. Kyiv, Naukova dumka, 280 p. (In Russian).

Senkovsky Y.N., 1987. Paleooceanography of Carpathian Cretaceous upwelling. Geological journal, №6, pp. 54-64 (In Ukrainian).

Senkovsky Y.N., Demchenko N.V., 1988. Paleogeographic reconstructions of location of the territory of oil- and gas-bearing provinces of Ukraine in Phamerozoic. Geology and Geochemistry of Combustible Minerals, 70. pp. 13-22 (In Russian).

Senkovsky Y., Grigorchuk K., Gnidets V., Koltun Y., 2004. Geological paleooceanography of Tethys ocean. Kyiv: Naukova dumka, 172 p. (In Ukrainian).

Senkovsky Y.M., Paliy V.M., Radkovets N.Y., 2012a. Paleooceanographic and geochemical sedimentary environments of Upper Vendian "black shale» phosphorite-bearing deposits of south-western margin of the East-European Platform. Geological journal, №1, pp. 22-30 (In Ukrainian).

Senkovsky Y.M, Koltun Y.V, Grigorchuk K.G, Gnidets V.P., Radkovets N.Y., 2012b. Anoxic events of Tethys ocean. Kyiv, Naukova dumka, 184 p. (In Ukrainian).

Schlanger S.O., Jenkyns H.C., 1976. Cretaceous oceanic anoxic events: causes and consequences. Geologie en Mijnbouw, № 3-4, pp. 179-184. the formation of the Menilite and Maykop Beds. In Carpathian part of the basin an oxygen-minimum layer covered the covered the medium-depths of the water column, providing the formation of the thick black shale succession of the Menilite Beds (Fig. 4B). Index OAE-4 is suggested to this anoxic event.

\section{CONCLUSIONS}

A concept, suggested in this study, is related to the theoretical basis of upwelling geology and problems of sedimentogenesis during the periods of oceanic anoxic events. The described anoxic events in the region were related to the existence of the upwelling effect, that is why they should be regarded to the range of the upwelling formations. Just the latter ones are to great extent related to the existence in the study area of oil, gas, phosphate raw material, silicites, black shales and other mineral resources.

Пастернак С. І. Волино-Подім^я у крейдовому періоді / C.І. Пастернак, Ю.М. Сеньковський, В.І. Гаврилишин. - Київ: Наукова Аумка, 1987. - 260 с.

Сеньковский Ю.Н. Аитогенез кремнистых толщ югозапада СССР / Ю.М. Сеньковський. - Київ: Наукова думка, 1977. - $280 \mathrm{c}$.

Сеньковский Ю.Н. Палеоокеанография Карпатского мелового апвемлинга / Ю.Н. Сеньковский // Геол. журн. 1978. - №6. - C.54-64.

Сеньковский Ю.Н. Палеогеографические реконструкции положения территории нефтегазоносных провинций Украины в фанерозое / Ю.Н. Сеньковский, Н.В. Аемченко // Геология и геохимия горючих ископаемых. - 1988. - №70. - С. 13-22.

Сеньковський Ю. Геологічна палеоокеанографія океану Тетіс. / Ю. Сеньковський, К. Григорчук, В. Гнідець, Ю. Колтун. - Київ: Наукова думка, 2004. - 172 с.

Сеньковський Ю. М., Палій В.М., Радковець Н.Я., Колтун Ю.В. Палеоокеанографічні та геохімічні умови сеАиментації верхньовенаських "чорносланцевих" фосфоритоносних віАкладів південно-західної окраїни Східноєвропейської платформи / Ю.М. Сеньковський, В.М. Палій, Н.Я. Радковець, Ю.В. Колтун. // Геол. журн. - 2012а, - №1. - С. 22-30.

Сеньковський Ю.М. Безкисневі події океану Тетіс / Ю.М. Сеньковський, Ю.В. Колтун, К.Г. Григорчук, В.П. ГніАець, Н.Я. Радковець - Київ: Наукова Аумка, 2012б. - 184 с.

Schlanger S.O., Jenkyns H.C., 1976. Cretaceous oceanic anoxic events: causes and consequences. Geologie en Mijnbouw, № 3-4, pp. 179-184.

Інституту геології і геохімії горючих копалин НАН України, ^ьвів, Україна spgk100@gmail.com 